\title{
SOMALI PIRATES TAKE TO THE HIGH SEAS: EXPEDIENCY OR LONG-TERM PIRATE STRATEGY?
}

\author{
Henri Fouche \\ Tswane University of Technology
}

\begin{abstract}
In 2008 the highest number of attacks recorded against ships in the world was reported to have taken place off the coast of Africa. These attacks were carried out at greater distances from land, along the east coast of Africa, than ever before. In this article the extent of piracy and armed robbery against ships in the African context and underlying causes of piracy and armed robbery against ships off the coast of East Africa will be presented. The objective is to analyse incidents and the land and sea based causes in East Africa to account for the shift in strategy from attacking ships in territorial waters to attacking ships on the high seas. A secondary aim is to determine, in view of the shifting background to the attacks, the responsibilities of navies and other role players in the process of countering such attacks. The article suggests that states need to review national legislation related to maritime security and that all state role players in the maritime domain need to cooperate more efficiently.
\end{abstract}

\section{Introduction}

Man has always carried his conflicts to the seas and threatened maritime security by disrupting good order at sea. Vulnerable unarmed merchant ships travelling at economic speed provide attractive targets in times of war for opposing sides intent on disrupting the flow of enemy commerce, and during times of peace for unscrupulous criminals bent on self enrichment.

Sun Tzu, a Chinese general two thousand years ago, remarked that all warfare is based on deception (Giles, 2003:9). This is often true of man's conflict at sea, whether in war or peace. During World War II Germany employed armed raiders disguised as merchant vessels to attack allied merchant shipping. Today high seas pirates use mother ships that are indistinguishable from bona fide fishing trawlers, 
from which to launch attacks against unsuspecting merchant vessels on the high seas.

A study by Dubner (in Meija and Mukherjee, 2004:324) on piracy and armed robbery against ships during the period 1989 - 1993 found that 61,8 percent of attacks occurred in the territorial waters of a country. The study also determined that the average distance of pirate attacks from shore is 11,55 nautical miles in the case of Indonesia, 68 nautical miles in Northeast Asia and 94,4 nautical miles in the South China Sea.

In 2008 the number of recorded actual and attempted attacks against ships off the coast of Africa surpassed the total for South East Asia with the highest number of attacks being recorded in the Gulf of Aden and Somalia. In 2008 successful attacks along the east coast of Africa were also carried out at greater distances from land than ever before. The inability of the Somali government to respond has encouraged the pirates who attack ships with virtual impunity (ICC, Jan 2009a:26). The only opposing forces are navies of the European Union countries, the North Atlantic Treaty Organisation (NATO) and other countries responding to the United Nations Resolutions 1816 (2008), 1838 (2008) and 1846 (2008) which call on states to take part in actively fighting piracy off Somalia by deploying naval vessels and aircraft. Pirates are, however, adapting to the naval presence by travelling further into the seas not guarded by warships of the United States and other countries (Rice in ICC, Jan 2009a:41). Should this trend continue ships in other vulnerable areas, previously unexploited by pirates, may become subject to attack as the pirates are forced to carry out their attacks further away from the heavily patrolled areas closer to the coast of Somalia.

Since 2008, in the Gulf of Aden and off Somalia, in contrast to previous patterns attacks are shifting from territorial waters to the high seas. Somalia adopted a territorial sea of 200 nautical miles width in 1972 and ratified the United Nations Convention on the Law of the Sea (UNCLOS) on 24 July 1972 but has not revoked the 1972 claim of a territorial sea of 200 miles (Treves, 2009:407). In the case of Somalia the shift to the high seas (beyond Somalia's $200 \mathrm{~nm}$ territorial sea) would seem to be of necessity due to the international naval forces patrolling the area. The need for a safe harbour close to the coast has apparently been overcome by the use of converted fishing trawlers, operating in tandem at long distances from the coast (ICC, 2009c:33). In the case of other states along the east coast attacks are escalating from theft from ships in port and at anchor to bold attacks on ships underway and specifically targeting high value cargoes in containers. The purpose of this article is to examine the impact the shift in tactics will have on the methods and strategies 
employed by littoral states to counter attacks and how it will impact on the role players responsible for maritime security.

The scope of the problem will be examined and offset against the underlying causes and shifting background of piracy to recommend appropriate responses to the high seas attacks.

\section{Extent of piracy and armed robbery against ships in the African context}

Between January 1998 and December 2004, the International Chamber of Commerce's (ICC) International Maritime Bureau recorded a total of 2450 actual and attempted attacks against ships worldwide. The number of incidents reported for this period, which took place against ships off the African coast (494) constituted $20 \%$ of the attacks worldwide. Most of these attacks were against ships berthed, at anchor or steaming in the territorial waters off the coast of Africa (ICC, Jan 2006:5).

Attacks against ships along the coast of Africa spiked in 2005 with a total of 35 actual and attempted attacks recorded against ships off Somalia. A concomitant rise in the number of attacks on ships in Nigeria led to Africa becoming the hot spot for piracy in 2008 by recording for the first time more attacks against ships (188) than South East Asia (55) and being responsible for $64 \%$ of the 293 incidents reported worldwide (ICC, Jan 2009a:5-6).

Due to the availability of arms in the Horn of Africa region, home to the collapsed state of Somalia, attacks against ships in this region were particularly violent with pirates prepared to fire automatic weapons and rocket propelled grenades at ships in order to stop them (ICC, Jan 2009a:24). On 2 June 2008 the United Nations Security Council passed resolution 1816 (2008) which called on states to take part in actively fighting piracy off the coast of Somalia by deploying naval vessels and aircraft. The subsequent build up of naval units supported by ship borne helicopters forced attackers to adjust their tactics by attacking ships further off the coast and moving their attacks to the high seas. This in turn increased the size of the area needed to be patrolled. In 2008 ninety-two ships were attacked in the Gulf of Aden, 19 off the coast of Somalia and 40 off Nigeria (ICC Jan, 2009a:5-6). The remaining attacks off the east coast took place off Kenya (2), Tanzania (14) and Mozambique (20). The rest of the attacks recorded in African waters took place off the west coast, Angola (2), Cameroon (2), Congo (2), Equatorial Guinea (1), Ghana (7), Ivory Coast (3) and Morocco (1). All of the attacks on the west coast took place within the territorial waters of states except for one attack on an oil installation 75 miles off the Nigerian coast (ICC, April 2009b).

In the first three months of 2009 thirty-six actual and attempted attacks were recorded against ships steaming in the Gulf of Aden / Red Sea, 15 against ships off 
Somalia and 2 against ships off Nigeria. During the same period 5 actual attacks were recorded against ships steaming in the Gulf of Aden and 5 actual attacks against ships steaming off Somalia with pirates attacking vessels far off the east and south coast of Somalia to avoid the increased number of warships patrolling the Gulf of Aden. Some attacks occurred up to approximately 600 nautical miles away from the Somali coast extending out to Kenya, Tanzania, the Seychelles and Madagascar and in one instance a bulk carrier reported an attempted attack 900 nautical miles from the coast. There has also been a cluster of attacks approximately 400 nautical miles southeast of Mogadishu.

All types of vessels, general cargo, bulk carriers, tankers, ro-ro vessels, fishing vessels, sailing yachts and tugboats are being targeted by the pirates (ICC, April 2009b). According to Kraska and Wilson (2008:41) the attacks so far from shore suggest that the pirates were using the shipping industry's open-access automatic identification system (AIS) to intercept merchant ships. Merchant ships on international voyages are required to transmit AIS data. Pirates at sea operating commercial equipment can also receive these signals and use the information to target ships. The International Maritime Bureau (IMB) points out, however, that the SOLAS permits the Master of a vessel the discretion to switch off AIS if he believes that its use increases the ship's vulnerability. The decision is at the discretion of the Master but current naval advice is to turn the AIS off completely along the coast of Somalia (IMB, Jan 2009a:5).

To carry out these attacks on the high seas, mother vessels capable of launching smaller boats to attack and hijack passing vessels are used. Once the attack is successfully carried out, the pirates sail the hijacked vessel towards the Somali coast and thereafter demand a ransom for the release of the vessel and crew. The question arises as to whether the high seas attacks are merely expedient to move beyond the concentrated range of naval vessels patrolling the Horn of Africa and Gulf of Aden region or whether it is a long- term strategy which in time may be adopted by pirates operating from other African countries. What indeed, except for the lack of a friendly coastline nearby, as with the case of Somalia, would prevent vessels on the high seas off other African countries from being hijacked and held to ransom?

With sophisticated technology and the use of trawlers operating together as support vessels and to keep the hijacked ship from being boarded in an attempt to rescue the hostages, pirates could hold vessels on the high seas for extended periods whilst negotiations for the release of crews and cargoes take place. With the gradual shift and gravitation from low level attacks against ships alongside or at anchor to attacks against vessels further out to sea and eventually to attacks using machine guns and rocket propelled grenade launchers on the high seas as has been the case 
particularly in attacks off the East Coast of Africa, such a scenario may become a future strategy. Such a strategy would shift the responsibility for intercession at sea from law enforcement agencies in the territorial waters to navies on the high seas.

\section{Underlying causes for East African piracy}

According to Hari (2009:13) although some modern pirates are clearly just gangsters, others are trying to stop illegal dumping and trawling. Campbell (2008:2) points out that illegal fishing and environmental abuses in Somalia are responsible for a dramatic loss of revenue in the local fishing communities. The environmental degradation has in turn catalysed desperate acts of maritime piracy in Somali waters. During a phone interview with a pirate leader on a hijacked oil tanker off the coast of Somalia the pirate claimed that they had done this to stop illegal fishing and dumping in their waters and that they just wanted money (Gettleman, 2008:1). The willingness of ship owners to pay large ransoms for the return of their vessels and cargoes has also provided an added incentive to engage in maritime crime (Chalk, 2009:3).

The question has also arisen as to whether such attacks are for self-enrichment or to strengthen the coffers of terrorist groups. Mwangura (in Logan, 2008:3) believes that at least some of the ransom money is finding its way into the hands of Islamist insurgents in Somalia. According to Mwangura the pirates are doing this on behalf of organised crime and for terrorist activities. Perpetrators of attacks against ships need specialised equipment and knowledge to operate on the sea. The most likely candidates to lead such attacks would be unemployed fishermen who have both the contrivances and knowledge to undertake voyages in the territorial waters and beyond. The question as to whether external groups such as extremists and terrorists use the pirates to procure funding for their own agendas and operations would seem to be unlikely unless the extremist and terrorist groups had infiltrated the pirate group (Muller, 2009). The only possible incentive for sharing part of the proceeds of their crimes with extremists and terrorist groups would have to be based on a longterm strategy of expelling foreign plunderers which would seem unlikely.

According to Daly (2008:3) there are indications that poverty and unrealised nationalistic ambitions in Somalia are causing a number of soldiers to turn to crime and join the Somali pirates. The availability of small arms in Africa, such as pistols, light / heavy calibre machine guns and automatic assault rifles and rocket-propelled grenades provide pirates with an enhanced means to operate on a more destructive and sophisticated level (Chalk, 2009:3). Coupled to unemployment and poverty this ready supply of arms makes piracy an easy alternative to earn a living through crime. The absence of a functioning navy, police force and civil authority to enforce 
laws has left Somalia helpless to prevent theft from taking place on the high seas in the vicinity of the Horn of Africa and the Gulf of Aden.

According to Lyman and Potter (2007:312-313) the core of syndicate activity in Africa revolves around black market business crimes committed by highly educated but frequently unemployed or underemployed young people. The east coast of Africa, further south from Somalia, with heavy volumes of traffic into ports like Mombassa and Dar-es-Salaam make these ports and anchorages attractive targets for opportunistic crimes. Attacks, however, are also becoming more sophisticated and in some instances ships are being specifically targeted for their cargoes. Perpetrators in these cases often attack while posing as agents for sellers who have prearranged for the sale of the stolen goods on the black market (Lyman and Potter, 2007:129). The underlying cause giving rise to such attacks lies not only in the poverty and unemployment on land in these regions but in lax coastal and port side security, enabling low-level attacks, especially harbour thefts and against ships at anchor to be carried out (Chalk, 2009:3). These attacks are also escalating and taking place further out to sea due to the inability of states on the eastern seaboard of Africa to effectively patrol their waters, either individually or jointly in co-operation with other states.

Further south South Africa has been spared from successful attacks against ships in South African waters. The factors which are likely to have contributed are a navy with capabilities to carry out patrols throughout the Exclusive Economic Zone, an inhospitable coastline with no ports for perpetrators to operate from, a strong economy with a functioning criminal justice system and the absence of the underlying causes as in the case of Somalia. South Africa has also criminalised piracy (SA, 2002) and the hijacking of ships in its waters (SA, 2004) in national law.

\section{Role players and shifting responsibilities in maritime policing}

For the purpose of this article maritime policing will be regarded as all the lawful actions undertaken by a state to create national laws, to administer such laws and conventions and the application of such laws to ensure formal social control in the area of a state's offshore jurisdiction.

The United Nations Convention on the Law of the Sea (UNCLOS), to which most African littoral states are a signatory, declares piracy in article 101 to be a criminal act which is committed on the high seas or in a place outside the jurisdiction of any state. Perpetrators of attacks on ships in ports, harbours and the territorial waters of a state cannot be charged with piracy, unless the state in whose territorial waters the attack has occurred has specifically criminalised piracy within its territorial waters in its national legislation. Canada and New Zealand are two 
countries that have adopted measures in their criminal code that criminalise piracy in terms of the law of nations within their area of jurisdiction (which includes their harbours, territorial waters, contiguous zone and extended economic zone (Fouché, 2006:39).

Perpetrators of armed attacks on ships in a state's territorial waters can be charged with common law offences such as robbery, murder, assault and damage to property. Perpetrators can also be charged under a state's statutory laws. The Convention for the Suppression of Unlawful Acts Against the Safety of Maritime Navigation (SUA Convention) obliges contracting states to create statutory provisions in their national laws to criminalise the hijacking of a ship.

South Africa (SA, 2004), Kenya (Kenya, 2009) and Tanzania (Tanzania, 2003) have criminalised the hijacking of ships in their national laws. Kenya and Tanzania have also made provision for the prosecution of persons who hijack a ship whether the ship is in Kenyan waters or elsewhere and whether the perpetrators are citizens of Kenya or Tanzania, or not, which would effectively mean that pirates who hijack ships on the high seas off Kenya and Tanzania can be prosecuted in those countries. This is an important legal provision given the controversy surrounding the procedures with regards to suspected pirates arrested off the east coast of Africa.

Hawkins (2009:1) points out that piracy is a universal crime and that each country may arrest pirates at sea and prosecute them at home, but that in practice, whether a country can prosecute arrested pirates depends on its own laws. He provides the example of the Danish Navy that detained and later released ten suspected armed pirates in September 2008 because Danish national law only provides for the prosecution of pirates in Denmark if they are accused of attacking a Danish ship or Danish citizens. Hawkins (2009:2) further points out that some navies are reluctant to detain the pirates they apprehend for fear of becoming legally responsible for them. As a result many suspected pirates apprehended by navies off Somalia are released without being prosecuted.

Law enforcement in the territorial waters of a state (including harbours as ports of entry) is generally entrusted to the police force of the state. In the case of South Africa, section 13(6) of Chapter 5 of the South African Police Service Act, empowers any member of the South African Police Service

- where it is reasonably necessary for the purposes of control over the illegal movement of people or goods across the borders of the Republic,

- without a warrant to search any person, premises, other place, vehicle, vessel or aircraft, or any receptacle of any nature, 
- at any place in the Republic within $10 \mathrm{~km}$ or any reasonable distance from any border between the Republic, or inside the Republic within $10 \mathrm{~km}$ or any reasonable distance from such territorial waters and

- seize anything found in the possession of such a person or upon or at or in such premises, other place, vehicle, vessel, aircraft or receptacle and which may lawfully be seized (SA, 1995:58).

Police forces or services are not the sole agencies entrusted with countering criminality and piracy at sea. Navies play a role as well and it is generally accepted that all navies fulfil three major functions for their country being diplomatic, policing and military (Bennett and Söderland, 2008:7). The same authors point out that the South African Constitution provides for a navy with a mandate to amongst others co-operate with other state departments in upholding and enforcing both international and South African law at sea.

The situation off the coast of Somalia in 2008 and the first quarter of 2009 where warships of several nations are conducting anti-piracy patrols has proven that concentrated naval intervention is effective in preventing attacks on ships, but is unable to stop the attacks. Pirates are adopting a strategy to attack ships further from the coast, to avoid the naval patrols, which is also curtailing the effectiveness of the patrols due to the vast area covered by seas off the coast of Africa.

The shift in strategy by pirates from attacking ships in territorial waters to ships on the high seas moves the responsibility for interdicting in such attacks from the police forces of states to that of navies. The United Nations Convention on the Law of the Sea (UNCLOS) in articles 105 and 107 empowers the warships or ships on government service of every state to seize a pirate ship on the high seas and arrest the persons and seize the property on board. Article 110 of UNCLOS justifies the boarding of a foreign ship on the high seas to verify the ships right to fly its flag if there is reasonable ground for suspecting that the ship is engaged in piracy. The courts of the state that carried out the seizure may decide upon the penalties to be imposed and the actions to be taken with regard to the ships, subject to the rights of third parties in good faith. Guyo (2009:1) points out, however, that in this regard the arrest and prosecution of pirates fall within the precinct of a state's national law. Successful prosecution would thus depend on whether the corresponding national legal standard exists and the degree to which the enforcing state has adopted the universal jurisdiction over piracy as an international crime that can be subject to arrest and prosecution anywhere in the world

Vrey (2008:14) avers that navies should be used to combat piracy on the high seas. The situation in the Horn of Africa has proved, however, that once assailants 
have boarded a vessel, actions by navies become handicapped because of the complexity of interests involved such as the nationality of the vessel, nationality of the crew, ownership of the cargo and the identity of the flag state. Given the aforementioned complexity and to prevent loss of life, the International Maritime Organisations draft Code of Practice for the Investigation of the Crimes of Piracy and Armed Robbery Against Ships (IMO, 2000:2) recommends that in any cases where persons on board have been abducted or held to ransom, the primary objective of any law enforcement operation must be their safe release and that their rescue must take precedence over all other considerations.

On 26 January 2009 the International Maritime Organisation (IMO) convened a meeting in Djibouti of 17 states from the Western Indian Ocean, Gulf of Aden and Red Sea areas to discuss cooperation in a manner consistent with international law, in interdicting and seizing suspect ships and the property on board such ships and rescuing ships, persons and property subjected to acts of piracy. The meeting adopted a code of conduct, effective from 29 January 2009, which was signed by nine countries in the region, being Djibouti, Ethiopia, Kenya, Madagascar, Maldives, Seychelles, Somalia, Tanzania and Yemen. The code of conduct is open for consideration for signature by the remaining 12 countries in the region, including South Africa. Signatories of the code of conduct undertake to review their national legislation with a view towards ensuring that there are laws in place to criminalise piracy and armed robbery against ships and adequate guidelines for the exercise of jurisdiction, conduct of investigation and prosecution of alleged offenders. The meeting was also attended by international bodies such as Interpol (IMO News, 2009:7).

Other international interventions to combat African piracy include a conference on 23 April 2009 held in Brussels and chaired by the United Nations Secretary General and the African Union Chairperson. The purpose of the conference, attended by politicians and donors was to mobilise the international community with the purpose of securing peace in Somalia. The European Union's Executive (the European Commission) pledged funds for, amongst other issues, rebuilding Somalia's law enforcement and criminal justice system (DPA, 2009:1). The importance of law enforcement in the fight against piracy was recognised by the Secretary General of Interpol who on 29 May 2009 pointed out during a G8 meeting in Rome that maritime piracy should be considered an international organised crime problem requiring a law enforcement investigative approach rather than a solely military response. In this respect he proposed the creation of an investigative prosecutorial taskforce based in the affected region (Interpol media release, 52/2009). 
The international dimension to the problem of combating piracy and armed robbery at sea, the need for cooperation between states and coordination of action was again emphasised during an anti-piracy conference on 19 May 2009 attended by governments, navies and shipping bodies held in Kuala Lumpur to discuss an initial resolution from more than 60 countries and the European Union. In the amended resolution which was adopted by the conference the United Nations is invited to consider further the possibility of taking joint measures through the European Union Contact Group on Piracy off the Coast of Somalia and its working groups to coordinate maritime force operations to suppress acts of piracy and armed robbery against ships along the coast of Somalia (France 24, 2009:1).

In 2005 Minister Ronnie Kasrils (the former South African Intelligence Minister) pointed out that even if all the African countries worked together to develop their maritime and naval power, their capacity would still be small when compared to the length of Africa's coasts and the size of African exclusive economic zones (Fouché, 2006:141). The answer however, does not only reside in optimising military ways and means. The Secretary General of the IMO on 26 January 2009 in Djibouti stated that it is in the best interests of the international community to continue developing multilateral cooperation agreements to put in place the strong infrastructure (legislative and practical) needed, and through alliances of governments to move to reduce the risk of attacks on merchant ships. Such cooperation include coordinated patrols in high risk areas, information sharing and intelligence exchange, and once an act of piracy or armed robbery has taken place against ships, to arrest, prosecute and detain the perpetrators (IMO, 2009:3).

Guyo (2009:2) agrees that the successful prosecution of the Somali pirates in Kenya on the basis of the bilateral arrangements provide both opportunities and challenges. He points out that such an arrangement provides a quick step to supplement the shortcoming of international law and demonstrates international partnership in fighting piracy as an international crime. It expedites the prosecution of the suspected pirates but Guyo warns, however, that the practice of bilateral arrangements to prosecute the crime of piracy goes against the International Law of the sea (Guyo, 2009:2). It also carries the risk of countries like Kenya becoming a target of reprisals from the crime syndicates.

South Africa is involved in African Union activities and through the South African Navy is committed to come to the assistance of states unable to police their own waters effectively against piracy. South Africa also has a number of bilateral navy-to-navy memoranda of understanding with various other nations and international groupings. In some cases these are the basis for international exercises with other navies (Bennett and Söderland, 2008:9). The South African Navy also 
maintains a naval coordination and guidance for shipping centre (NCAGS). The NCAGS has a strategic function that aims to protect merchant shipping, including that of South Africa's trading partners from regional tensions, piracy or other forms of aggression (Von Ziel, 2005:1).

Vreÿ (2008:14) suggests that in instances where states have a limited capability to protect their interests at sea they may consider procuring the services of private security companies to augment their shortcoming. He also proposes that private security guards could be placed on board vessels navigating danger areas. This deterrent to would-be pirates could also be strengthened by the presence of patrolling warships in the area (Vrey, 2008:14). In a different vein, the Djibouti Code (adopted on 29 January 2009) by participating states makes provision in article seven for participants to nominate law enforcement officials to embark upon ships on patrol of another participant with the purpose of assisting the host participant and conducting operations from the host participant ship. The so-called "shipriders" in the shiprider agreements are called for in United Nations Security Council Resolution 1851. Such embarked law enforcement officials would greatly enhance the investigation and assist the state prosecuting the arrested pirates with good evidence for court purposes. Thus the combination of private security on commercial vessels and embarked law enforcement officials on patrolling naval vessels may provide an effective deterrent to would be offenders

Cooperation among states in terms of joint patrolling, the sharing of intelligence and the investigation and prosecution of alleged offenders remains the most important means to combat piracy. States need to look at ways of enhancing cooperation between their own navies, police forces and state departments tasked with maritime security. States also need to have a maritime capability able to protect their sovereignty in the maritime domain as well as a functioning criminal justice system if piracy is to be kept in check or eradicated.

\section{Conclusion}

In the light of the 2009 Djibouti conference the national legislation of states needs to be re-examined with the view to possibly collate all national maritime security related legislation in one act. A common act can promote regional harmonisation of laws for a uniform approach to the arrest, investigation and prosecution of offenders. Naval personnel must have knowledge of the provisions of the international conventions and the relevant national legislation of the state empowering them to act on the high seas and within their exclusive economic zones against piracy and other acts of maritime violence. Navies need to cooperate with fellow departmental role players of their state in the maritime domain - the police and judiciary in particular. States also need to cooperate with other states in their 
region in terms of joint maritime patrols, the sharing of information on piracy and the joint investigation of piracy and armed robbery of ships.

In light of the constant shifting background to acts of piracy and armed robbery against ships and the ever-increasing sophistication apparent in the methods of attack is it likely that pirates may shift their field of operations all the more away from the lucrative targets in the territorial seas close to their land bases to the high seas. In a sense such a shift could well be a case of necessity being the mother of invention. The most likely long-term solution to the problem of piracy off Somalia is the creation of a stable state in Somalia with a functioning criminal justice system and the means to apprehend perpetrators. Until such a time, a viable alternative to the preventative patrols in the area by the navies of many nations of the world seems to lack. At the moment, the naval response apparently forces the pirates to seek unprotected targets further and further out to sea. Only time will tell whether more effective counter-piracy operations will have the long-term effect on pirates to change their locus of operations, away from the coastal areas to the high seas. Such a move would necessitate a concomitant change in tactics by states.

\section{BIBLIOGRAPHY}

Bennett, C.H. and Söderland, A.G. 2008. South Africa's Navy, Simon's Town: SA Navy.

Chalk, P. 2009. Maritime piracy reasons, dangers and solutions: Testimony before the United States House of Representatives, February 4. Available at: www.rand.org [Accessed: 23/04/2009].

Campbell, C. 2008. Effecting a sea change: Changing tack to heal the wounds of African piracy. Available at: http://earthjuris.org/publications_/ ejstudentseries/CAmpbell.pdf [Accessed: 26/04/2009].

Daly, J.C.K. 2008a. Terrorism and piracy: The dual threat to maritime shipping, Terrorism Monitor, 6(16), August 11, Published by the Jamestown Foundation. Available at: http://www.jamestown.org/terrorism/news/article.php?articled=2374367 [Accessed: 24/04/2009].

DPA, 2009. Brussels hosts donor conference for Somalia security. Available at: http://www.earthtimes.org/articles/printhistory.php?news=265564 [Accessed: 23/04/2009].

Fouché, H. 2006. Policing piracy and armed robbery of ships in South Africa's territorial waters and contiguous zone, D Tech thesis, Tshwane University of Technology, Unpublished. 
France 24, 2009. Anti-piracy conference backs off on international naval force, 19 May. Available at: http://www.france24.com/en/20090519-anti-piracy-body-backs-offinternational-nava... [Accessed: 02/06/2009].

Gettleman, J. 2008. Somali pirates tell all: They're in it for the money, The New York Times, September, 30. Available at: http://www.nytimes.com/2008/ 10/01/world/africa/01 pirates.htm?r=1\&scp=1\&sq=so [Accessed: 01/10/2008].

Giles, L. 2003. The Art of War: Sun Tzu, Translated by Lionel Giles, New York: Barnes and Noble Books.

Guyo, M. 2009. Taking the Somali pirates to court, ISS Today, 15 April. Available at: http://www.issafrica.org [Accessed: 20/04/2009].

Hari, J. 2009. The truth about modern pirates, The Sunday Independent, 11 January, 13.

Hawkins, O. 2009. What to do with a captured pirate? BBC News, Special reports 10 March. Available at: http://newsvote.bbc.co.uk/mpapps/pagetools/print/news.bbc.co.uk/ 2/hi/in_depth/7932 [Accessed: 01/06/2009].

ICC. (International Chamber of Commerce). 2006. International Maritime Bureau, Piracy and armed robbery against ships, Annual Report 1 Jan - 31 Dec 2006, January edition, Essex: Maritime House.

ICC. (International Chamber of Commerce). 2008. International Maritime Bureau, Piracy and armed robbery against ships, Quarterly Report 1 January - 31 March 2008, April edition, London: Cinnabar Wharf.

ICC. (International Chamber of Commerce). 2009a. International Maritime Bureau, Piracy and armed robbery against ships, Annual Report 1 January - 31 December 2008, January edition, London: Cinnabar Wharf.

ICC. (International Chamber of Commerce). 2009b. International Maritime Bureau, Piracy and armed robbery against ships, Annual Report 1 January - 31 March 2009, April edition, London: Cinnabar Wharf.

ICC. (International Chamber of Commerce). 2009c. International Maritime Bureau, Piracy and armed robbery against ships, Quarterly Report 1 January - 30 September 2009, London: Cinnabar Wharf.

IMB. 2009. Best management practices to deter piracy in the Gulf of Aden and off the coast of Somalia, February.

IMO. 2000. Draft Code of Practice for the Investigation of the Crimes of Piracy and Armed Robbery against Ships, MSC/Circ 984, 20 December. 
IMO. 2009. Sub-regional meeting to conclude agreements on maritime security, piracy and armed robbery against ships for states from the Western Indian Ocean, Gulf of Aden and Red Sea areas, Djibouti, 26 January. Available from: http://www.imo.org/About/mainframe.asp?topic_id=1774\&doc_id=10929 [Accessed: 02/06/2009].

IMO News. 2009. Issue 1, London: Encompass.

INTERPOL media release, 2009. Law enforcement is "missing link" in fight against maritime piracy, Interpol Chief tells G8 meeting, 52/2009, 29 May, Surveillance, Johannesburg: South Africa, Unpublished.

Kenya, 2009. The Merchant Shipping Act.

Kraska, J. and Wilson, B. 2008. Fighting pirates: The pen and the sword, World Policy Journal, MIT Press.

Logan, M. 2008. Piracy off Somali coast linked to strategy to bolster the capacity of insurgents, Cape Times, August 28:3.

Lyman, M.D. and Potter, G.W. 2007. Organised Crime, $4^{\text {th }}$ Edition, Upper Saddle River, New Jersey: Hamilton Printing.

Muller, D. 2009. Interview, Pretoria.

Meija, M. and Mukherjee, P.K. 2004. Selected issues of law and ergonomics in maritime security, Journal of International Maritime Law, 10(4) August September, 301-325.

SA. 1995. South African Police Service Act, Act 68 of 1995.

SA. 2002. Defence Act, Act 42 of 2002.

SA. 2004. Protection of Constitutional Democracy against Terrorism and Related Activities Act, Pretoria: Government Printer.

SUA. 1988. Convention for the Suppression of Unlawful Acts against the Safety of Maritime Navigation, New York: United Nations.

Tanzania, 2003. The Merchant Shipping Act, Dar-es-Salaam: Government Printer.

Treves, T. 2009. Piracy, Law of the Sea, and the use of force: Developments off the coast of Somalia, European Journal of International Law, 20(2).

UNCLOS. 1982. United Nations Convention on the Law of the Sea, New York: United Nations. 


\section{1}

Vreÿ. F. 2008. Só kan plan gemaak word met die seerowers, (This is how pirates can be dealt with) Rapport, November 16.

Von Zeil, G. 2005. Naval co-ordination and guidance for shipping (NCRGS), Available from: http://www.navy.mil.za/forecastle/:051107NCAGS/article.html [Accessed: 18/11/2005]. 